\title{
China and India's Economic Transition and its Challenges in the Post-crisis Period
}

\author{
Haibin Yang \\ School of International Business, Yunnan University of \\ Finance And Economics \\ Kunming, China \\ e-mail: haibinyoung@foxmail.com
}

\author{
Xuemin Ding* \\ School of International Business, Yunnan University of \\ Finance And Economics \\ Kunming, China \\ e-mail: 812557705@qq.com
}

\begin{abstract}
To effectively solve China's and India's economy faces many challenges, we must deeply realize that the two countries belong to the late-development country, at the technical level in the realistic background of economic system is in transition period. Thus, this paper argues that in the current between the two countries under the condition of entering a new stage of economic openness, must change the original simple rely on the resources and capital investment for growth, achieving to rely mainly on the development of the ability of independent innovation strategy on the basis of structural transformation.
\end{abstract}

Keywords-the post-crisis era; China; India; economic transition

\section{INTRODUCTION}

There is no doubt that the Chinese dragons and Indian elephants, the two ancient Asian civilizations, have drawn the world's attention from the wonders of economic growth that began in the 1980s and 1990s, respectively. This phenomenon has also aroused wide interest in the academic community. The development of China and India in the 21st century can arouse worldwide attention and comparison. Apart from the economic factors, there are too many similarities between China and India: First, the two countries are geographically separated by an identical border; Second, both countries are populous countries with a population of more than 1 billion .once again, the two countries have created their own prosperity in history, and until nineteenth Century is the leader of the world's economy; Finally, in the past 30 years, the two countries successively carried out an unprecedented economic reform from the late 1970s and early 1980s, The result of this reform has led to a significant event in the history of the world economy since the Second World War - the two most populous countries in the world have enjoyed rapid economic growth at the same time and have had a significant impact on the political and economic situation in the world.

It is generally believed that the miracle of economic growth in China and India in the recent 30 years mainly comes from the institutional reform of the two countries [1]. Of course, in addition to its own internal institutional changes, the two countries have also become one of the biggest winners of economic globalization after World War II through market opening. Although the economic performance of China and India is quite different in terms of structure and content, it is undeniable that both countries have experienced similar economic development paths. Particularly after experiencing the worldwide financial crisis in 2008, China and India have become the engines driving the global economic recovery. People of insight in both countries have come to realize that as a typical large-scale economy, China and India need to rebalance the world economy. The first wave of global dividends has been overdrawn of basing on export orientation and low-end elements to join the global value chain in the past impossible to continue to develop, The economic development strategy of China and India urgently needs transformation and upgrading.

From the past experience of western developed countries, modern economic growth is based on technology, business and industrial structure evolution and development on the basis of the knowledge, The development of national capabilities, which is based on knowledge, organization and system, has undoubtedly become the key variable in this process of economic development. Therefore, This article will focus on the many challenges China and India face , discuss how to complete economic restructuring between the two countries under the condition of economic opening.

\section{CHINA AND INDIA'S ECONOMIC DEVELOPMENT PATH COMPARISON}

In the opinion of the French historian Braudel, as the second largest economy in the Far East in the 15th and 18th centuries, India's economy in the June 23, 1757 battle of Plasser (Plassey Campaign) gradually controlled by the East India Company, and Chinese decline slightly later than India, India started its opium shipment to China in 1780 ,the fate of China in the nineteenth century became a replica of India's fate in the 18th century [2].In fact, many economists have also made an in-depth study of the economic growth and stagnation in China and India development history [3][4]. They found that at least between the 1000-1820 AD, more than half of the world's total GDP was contributed by China and India. However, the share of the two economies in the world's GDP fell to $30 \%$ in 1870 , and decreased to less than $10 \%$ in 1950 1973 years, as shown in Figure 1.

In addition, From a long history of point of view, It is also very interesting to compare the corresponding changes in economic growth between China and India respectively with

\footnotetext{
*Corresponding author
} 
Western Europe, the United States and the world economic growth As can be seen from Figure 1, the share of Western Europe in world GDP rose from $9 \%$ in 1000 AD to $33 \%$ in 1870, However, in the years 1950-1973 dropped to $26 \%$; the United States rose from $2 \%$ in 1820 to $27 \%$ in 1973, which clearly shows that the United States began to surpass Western European countries become the locomotive of the world economy after the second world war. In contrast, China and India's economy have maintained a high growth rate of $6 \%$ $10 \%$ since 1980, while the economic growth of the United States, Western Europe and Japan in the same period is weak. Even in the recent economic crisis, although the speed has been reduced, the two giants in emerging economies have maintained positive but not negative growth rates. Studies have shown that the potential of the two countries to grow in the future is great, but India will have greater potential for development [5].

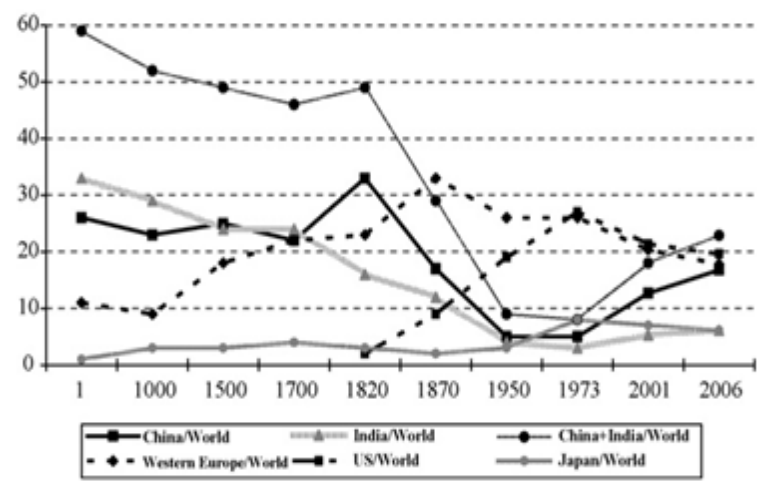

Fig. 1. Comparison of the economic performance between China and India during the period of $\mathrm{AD} 1-6$

From the 90s of last century, the world economic pattern gradually completed a large-scale shift of focus from west to east and from north to south. In this regard, some economists believe that this shift in the global economy is largely due to the level of technological development in emerging markets and the maturity of the national economy [6]. Since entering the 21st century, with the accession to the WTO as a symbol, as a "locomotive-oriented" country representing the economic growth of developing countries for nearly 30 years China and India have obviously accelerated their pace of integration with the world economy and have grown into an open economy with the most FDI in foreign direct investment and high dependence on foreign trade. However, Behind the unprecedented $6 \%$ to $10 \%$ economic growth rate in China and India, one issue that can't be ignored is that as China and India deepen their transformation toward industrialization and urbanization, both economies are undergoing significant structural changes, Its original mode of economic development is facing new challenges. In particular, since the world financial crisis, the dividends of the first wave of globalization-based export-led development based on low-end elements joining the global value chain have been overdrawn due to the reduction of demand in industrialized countries. The era of "structural acceleration" brought about by the simultaneous high growth brought about by the industrialization of the two countries tends to end and the economic growth will gradually shift to the "structural deceleration" of the future [7]. Therefore, in the post-crisis era, China and India must resume their economic development as soon as possible

According to the theory of the economic growth stage of W. Rostow, the famous economist of the United States, both China and India are in the stage of economic take-off in the current economic development period. Therefore, both China and India have gone through three basic processes in general, namely, The transformation of economic system, the transformation and upgrading of economic structure and industrial structure, and the transformation of the foreign economic relations. Although China and India are closer to the policy ideas of economic reform and development, there are also many differences between the two countries in specific development paths and Countermeasures due to their differences in resource endowments and economic structure. The specific performance is the difference between three aspects:

First is the difference of economic structure between the two countries: In India's industrial structure, at present is the 321 sequence, Among them, the added value of service industry and industrial industry accounted for $53.4 \%$ and $29.2 \%$ of GDP respectively, while the added value of agriculture industry accounted for only $17.4 \%$ of GDP, Therefore, India has a "world office" in the world; ; And as a "world factory", China's industrial structure maintained the traditional sequence of 231, Among them, the added value of industry, service industry and agricultural industry accounted for $49 \%$ of GDP, $39.9 \%$ and 11.15 respectively.

Second, the two countries have different economic impetus: : In India's growth momentum, due to the middle class with 2-3 billion people,, so India's economic growth is mainly rely on domestic consumption to promote, the function of foreign trade is not prominent; However, China's economic growth mainly comes from the government's investment and export trade. The domestic consumption capacity of domestic residents is not enough, and its effect on the economy is not significant.

Third, the two countries have different economic development strategies: In the context of India's development strategy, its development strategy pays more attention to the balanced development with a view to avoiding any widening of the gap between economy. 
TABLE I. CHINA AND INDIA'S COMMODITY TRADE INDEX FOR 1980-2012 YEARS

\begin{tabular}{|l|l|l|l|l|l|l|l|l|l|l|l|l|l|}
\hline country & Indices & $\mathbf{1 9 8 0}$ & $\mathbf{1 9 8 5}$ & $\mathbf{1 9 9 0}$ & $\mathbf{1 9 9 5}$ & $\mathbf{2 0 0 0}$ & $\mathbf{2 0 0 2}$ & $\mathbf{2 0 0 4}$ & $\mathbf{2 0 0 6}$ & $\mathbf{2 0 0 9}$ & $\mathbf{2 0 1 0}$ & $\mathbf{2 0 1 1}$ & $\mathbf{2 0 1 2}$ \\
\hline \multirow{3}{*}{ China } & Export & 7 & 10 & 24 & 59 & 78 & 130 & 238 & 388 & 488 & 573 & 482 & 633 \\
\cline { 2 - 14 } & Import & 8 & 18 & 23 & 58 & 73 & 131 & 249 & 351 & 424 & 502 & 446 & 619 \\
\hline \multirow{3}{*}{ India } & Export & 20 & 21 & 42 & 72 & 84 & 118 & 180 & 287 & 353 & 459 & 389 & 511 \\
\cline { 2 - 13 } & Import & 28 & 30 & 45 & 67 & 91 & 109 & 193 & 346 & 443 & 622 & 499 & 628 \\
\hline
\end{tabular}

a. data sources: International Merchandise, Trade, Merchandise Trade indicator, www.unctad.org

It is precisely because of the differences in the three major development paths mentioned above that there has been a huge difference in the rate of growth between China and India First of all, China's economic growth reached a peak of $9 \%$ in 2007, After 2008, it was affected by the financial crisis and dropped to the $6 \%-7 \%$ range in 2012, but over the years has been the forefront of global economic growth; while India's economic growth rate is not stable, large fluctuations, the average annual growth rate during the period from 1991 to 2010 to maintain in $6 \%$ After 2012, it started to have a high growth rate of nearly $8 \%$, which directly led to the expansion of the economic gap between the two countries. Secondly, calculated by GDP per capita, China's per capita GDP increased from 373 US dollars to 5432 US dollars during the 1991-2011 years, which increased by 14.5 times. Meanwhile, in the same period, the per capita GDP in India increased from 315 US dollars to 1530 US dollars, a mere increase of 4.8 times. It can be seen that the average GDP per capita in China and India in the 90s of last century is only about 300 U.S. dollars, and the gap is not large. But after nearly 20 years of development differences, the economic gap between the two countries has become very large Finally, comparing the urbanization rates of China and India, although India accounted for $17.3 \%$ of the urban population in the $1950 \mathrm{~s}$, it is higher than the urban population, which is $12.5 \%$ higher than China. However, China's urbanization rate has risen to $52.6 \%$ in 2012, while in India it is only about $30 \%$.

\section{THE MAIN CHALLENGES FACING CHINA AND INDIA'S ECONOMIC TRANSFORMATION}

According to the latest report released by OCED in November 12, 2012, According to the latest OCID report released on November 12, 2012, its September composite leading indicator (CLIs) was 100.2, unchanged for the third consecutive month. This indicator is mainly used to reflect the economic activity of the 34 member countries to which the OECD belongs. At the same time A comprehensive leading indicator for the OECD for large emerging economies can be found, Brazil's economy is still expanding, the country's September composite leading indicator rose from 99.4 in August to 99.5; China's economy showed signs of stabilization. the composite in September leading indicators remained flat with August, 99.4; India's composite leading indicator slipped to 96.8 in September from 97.1 in August. Russia has fallen from 99.2 in August to 99, the two countries showed a slowdown in economic growth. In this context, since the second half of 2012, countries such as China, India and Vietnam have chosen to cut interest rates one after another, and the economy of emerging market economies has cooled down significantly. At the same time, "keeping growth" has gradually become the primary option for more and more developing countries' government macroeconomic policies. Of course, for different emerging market economies, Due to the disparity between the conflicting objectives of "suppressing inflation" and "maintaining growth" among different countries, Therefore, the policy space in choosing to maintain growth is not the same, leading to the differentiation of the economic development modality among these emerging economies. China and India are no exception. Both of them need to face the pressure of slowing economic growth and must make appropriate policy adjustments accordingly.

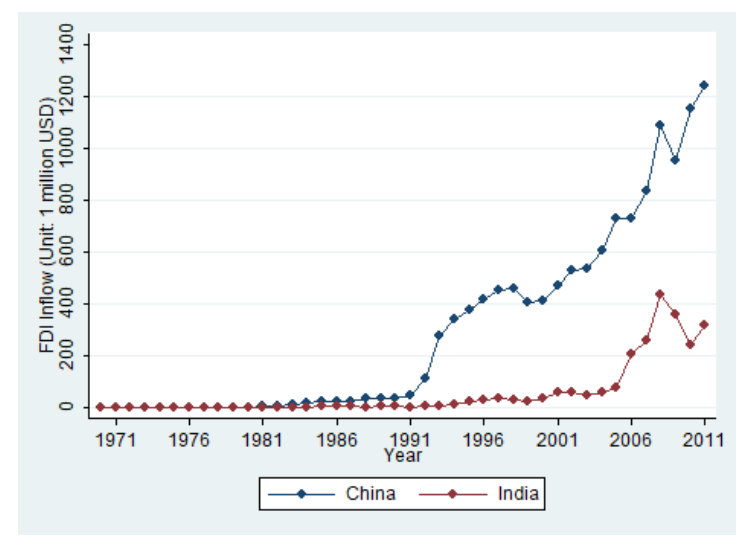

Fig. 2. FDI in China and India from 1970 to 2011

An interesting phenomenon can be found from Figure 2. China's economic reform started in 1979, and India's economy began to take off from 1982. Correspondingly, FDI inflows in both countries also fluctuate with economic growth. This also fully illustrates the correlation between FDI and economic growth, That is, with the inflow of FDI, the national capabilities of China and India have been raised and thus have a positive effect on economic growth, Of course, we are more interested in that, If there is a backward advantage of China and India due to technological advances, and quickly catch up with the developed countries, So what causes the TFP (Conditional) Convergence caused by technology spills? For the change of national ability caused by FDI introduction, Is there a more fundamental mechanism of action that determines the differences in growth performance between China and India?

Currently, as far as the developing economies are concerned, the overall economic growth has few regional or industrial balance, China and India are no exception. At present, China and India face many difficulties in economic growth. There are mainly problems such as irrational dynamic structure of growth, extensive growth, imbalance of industrial structure and ecological environment imbalance. Historically, the United States and other economic powers rely on the 
capability of transformation and innovation to ensure their own competitive advantages. Therefore, if China and India want to smoothly cross their own growth bottlenecks and achieve economic restructuring, they will inevitably need to solve two challenges:

First, how to solve the imbalance in the industrial structure. In general, in the history of human economic and social development, the industrial structure development always follows the sequence of agricultural society, industrial society, knowledge and service society, This law also applies to big nations. Historically, India and China were once agricultural countries before the economic rejuvenation In the fifties and sixties of last century, both experienced the stage of development from agriculture to industrialization. The industrialization paths of the two countries were similar. They all chose to give priority to the development of heavy industry., The difference is that, after entering the late 1970s, China adopted the "reform and opening up" policy and seized important opportunities for the transfer of manufacturing industries in western countries. First, it first supported the large-scale development of township and village enterprises in the 1980s, and then introduce a large number of foreignfunded enterprises and foreign investment, These measures not only speed up the pace of industrialization on the one hand, but also absorb the huge rural surplus labor force and directly promote China's economic miracle of 30 years of industrialization, urbanization and rapid economic growth. Compared with China's development path, India has not chosen to vigorously develop its manufacturing industries due to the huge rural unemployed and poor population, resulting in its slow urbanization process. However, India also made full use of its human capital advantages. After entering the 90s of the 20th century, it seized the opportunities of western developed countries' service outsourcing and vigorously developed the high level service industry. In general, the imbalance of industrial structure between China and India is still outstanding. Especially the third industry occupies a low proportion in GDP, which directly affects the economic efficiency of both countries. In the future, both countries must strengthen technological innovation level and strive to transform to high technology and high added value industries.

The second is how to adjust the development strategy of the two countries under the conditions of economic liberalization. Many underdeveloped countries have adopted various policies to promote the industrialization level of the country after the Second World War. China and India are no exception. To this end, to this end the two countries to imitate the Soviet model adopted a catch-up strategy on economic, trying to prioritize the development of capital-intensive heavy industries. However, pursuing a long-term catch-up strategy will not only affect development performance and the speed of technological innovation, but also affect regional development imbalances and income distribution. In particular, the economic growth in China and India is driven mainly by investment, once the domestic and foreign funds are hard to continue to invest, the economy will inevitably stagnate. China and India joined the WTO in the 1990s, its economic opening to the outside world will increase, and changes in international trade and finance will have a significant impact on the national economy of both countries. Therefore, after entering the 21 st century, China and India started the marketoriented economic reform and transformation spontaneously,. The aim of the reform is to restore the market's resource allocation function and reduce the government's intervention in the economy.

\section{CHINA AND INDIA: HOW TO CHOOSE THE ROAD OF TRANSFORMATION}

Since the second half of 2011, The shadow of the financial crisis is still enveloped in emerging market economies," Maintain growth and curb inflation" has become the main economic goal of developing countries such as China, India and Vietnam. According to the latest report released by OCED in February 11, 2013, its comprehensive leading indicator (CLIs) increased to 100.4 in 2012 December, indicating that the economic situation of the world's leading powers is improving. In the meantime, from the comprehensive leading indicators prepared by OECD for large emerging economies, it can be found that the Chinese economy shows signs of stabilizing, September 2012 composite leading indicator unchanged from August, both 99.4; India's composite leading indicator slipped to 96.8 in September from 97.1 in August, indicating a slowdown in economic growth in both countries. The reason is mainly due to the fact that both China and India currently lack new support points for economic growth and the original growth model is facing the challenge of the domestic and foreign market environment.

The experience of economic transformation in developing countries indicates that selective adjustment of development strategy according to national capacity and comparative advantage is a basic condition for most developing countries to remain competitive. Of course, it is undeniable that China and India have not achieved their due achievements in changing the way of growth, facing many challenges and bottlenecks in promoting growth and transformation. Over the next ten years, if China and India continue to follow the pattern of high energy consumption in industrialized countries, it will be hard to carry the needs of nearly 2.6 billion huge populations in both countries even if they use the entire earth's environment and resources. In particular, China and India are still heavily dependent on government - led capital investment to promote economic growth. This causes the proportion of manufacturing industry in the two countries' industrial structure is rather high, while the proportion of technology intensive industry and service industry is relatively low, which can't meet the needs of the global market. Due to the longterm economic dependence on the extensive development of external technologies and funds, which has hindered the growth of the capabilities of China and India, Therefore, when the international economic environment changes, the growth rate of both countries will slow down. In the future, the economic development of China and India will still face a lot of uncertainty. It is an unknown number to succeed in crossing the Middle Income Trap and realizing the economic transformation. For China and India, which are facing the critical period of economic restructuring, they will suffer greater setbacks and challenges in the future if they can't achieve true development in the building of national 
capabilities based on independent innovation, In the post-crisis era, China and India must change the traditional mode of growth, which aims at catching up and surpassing as soon as possible, And they need to solve the economic restructuring difficulties of the two countries in the following three aspects in order to maintain their pace of development:

First, strengthen the endogenous growth ability based on institutional innovation. China and India must pay attention to the impact of international trade on the diffusion and spillover of technology in order to achieve rapid industrialization and sustainable economic growth. Under the open economy, developing countries are often able to get the opportunity of learning and technology spillover from the import and export of products, which in turn reinforces the dependence of technological progress on trade. The path of technological progress in China and India shows that we need to further improve the openness of the economy. Only by deepening the role of trade in technology spillovers can we promote the two countries to move closer to the technology frontier as soon as possible. From an external point of view, trade liberalization is crucial for the growth of capacity in India and China. Reducing tariff barriers and encouraging imports is the key to productivity growth, because only in this way can the domestic economy truly integrate into international competition and motivate domestic enterprises to learn from abroad Of the advanced technology, their products have international competitiveness. Due to the financial crisis has a greater impact on the two countries, especially the impact on China's exports is extremely obvious, and led to economic growth slowed down, reflecting the emerging economies because the lack of self-capacity growth problems. Therefore, in the post-crisis era, China and India should raise their endogenous capacity as soon as possible and change the traditional model of over-reliance on investment and exportled economy Instead, they should attach importance to the social security system and the income distribution system construction and strive to expand the size of the middle class and the space for domestic demand growth. Based on the domestic market, they are the fundamental guarantees for the long-term sustainable development of both countries.

Second, adjust the economic structure and make efforts to form the comparative advantage of the national resource endowment. Economic theory tells us that the economic structure of developing countries must conform to their comparative advantages of resource endowments, so as to promote the speed of economic development and maintain the stability of national economic operation, especially the stability of financial system. The experience of developing countries such as China and India has proved that free trade has not locked them in a backward position, but gave them a dynamic comparative advantage characterized by outwardoriented development. In order to maintain comparative advantage, it is necessary for China and India to continue the policy intervention, especially the strategic economic policy to guide the development of our industry so as to solve the structural imbalance in the economy. Judging from the characteristics of technological progress in China and India at present, it has neither gained the upstream position in the international industrial chain nor realized the dynamic and optimal allocation of resources in the rapid economic growth. The sustainability of the future is facing serious challenges. Therefore, both governments need to state capacity and technological progress combine to carry out independent innovation as the core of the economic development mode as soon as possible, So as to promote the transformation of technological progress, organizational behavior and institutional system so as to realize the transformation of the mode of economic development between China and India through the growth of national capabilities

Third, improve technological progress, especially the contribution of technological innovation to growth. According to the theory of new economic growth, the direct meaning of technological progress is the extrapolation of technological frontiers, While countries with poor initial technological level will have faster technological advancements in the future than those with advanced technological levels. At the same time, if the technology absorptive capacity of a country based on knowledge accumulation is relatively weak, it is difficult to get the benefits of technology spillover from trade, and it is very difficult to form dynamic comparative advantage. With regard to the economic transformation that China and India now face, Whether it is engaging in international trade or participating in global division of labor, the dynamic of comparative advantages is a crucial prerequisite. The reason is that, on the one hand, with the accumulation of China and India's technological progress and the accumulation of capital and other elements . The emergence of division of labor and specialization will prompt foreign trade and industrial structure to evolve from a lower level to a higher level and eventually form a spontaneous process and trend of dynamic comparative advantage. On the other hand, in order to better integrate into the existing the international division of labor and industrial chain and benefit from, China and India must also adhere to the path of development of the comparative advantage from the exogenesis to the endogen. In fact, only when China and India form dynamic comparative advantages can they really change their position in the division of international trade and achieve the internal innovation mechanism of technology and industrial upgrading. This is undoubtedly the foundation for China and India to successfully achieve economic transformation in the future. To this end, China and India need to increase investment in independent research and development, change the way of technology progress that used to introduce and update equipment and rely on technological innovation to drive technological progress.

From the above analysis of the path of economic restructuring between China and India, we can see that, In the future, the economy of China and India will face many changes. For example, the high savings rate will be adjusted, the low-cost advantage of labor will gradually weaken, the difficulty of enhancing total factor productivity will increase, and the constraints of resources and environment will be significantly strengthened etc.. Under the background of economic globalization, both countries need to quickly build a comparative advantage based on technological innovation capability to meet the challenges of the future. Therefore, China, India and other developing countries would like to 
complete the economic restructuring, which must change their original model that relies simply on resources and capital inputs to gain the technological pattern to technology and thus achieve a structural shift toward capacity development that relies mainly on independent innovation strategies.

\section{REFERENCES}

[1] T. N. Srinivasan, "China and India: economic performance, competition and cooperation: an update, Journal of Asian Economics", Vol. 15 (4) pp. 613-636, 2004.

[2] Braudel. "Civilisation materielle, economie et capitalisme : XVe-XVIIIe siècle”, Paris: Librairie Armand, 1979.
[3] A. Maddison, "Chinese Economic Performance in the Long Run, 9602030AD(Second Edition)", Paris: OECD Development Centre, 2007.

[4] B. Bosworth, S. M. Collins, "Accounting for Growth: comparing China and India", Journal of Economic Perspectives, Vol. 22(1), 45-66, 2008.

[5] L. Pritchett, "A review of Edward Luce' $s$ in spite of the gods: the strange rise of modern India", Journal of Economic Literature, Vol. 47, 2009: pp. 771-780.

[6] J. Haltmaier, A. Shaghil, B. Coulibaly, R. Knippenberg, S. Leduc, M. Marazzi and B.A. "Wilson, The Role of China in Asia: Engine, Conduit, or Steamroller? Board of Governors of the Federal Reserve System", International Finance Discussion Paper, pp. 904, 2007.

[7] H. B. Yang, X. M. Yang, "National capacity, comparative advantage and economic transition". ideological front, 2012. 